\title{
THE ROLE OF THE
}

\section{EXCHANGE RATE}

\section{FOR ADJUSTMENT}

\section{IN BOOM AND \\ BUST EPISODES}

by Reiner Martin, Ludger Schuknecht and Isabel Vansteenkiste 
EUROSYSTEM

\section{WORKING PAPER SERIES} NO 8 I 3 / SEPTEMBER 2007

\section{THE ROLE OF THE EXCHANGE RATE FOR ADJUSTMENT IN BOOM AND BUST EPISODES I}

by Reiner Martin,

Ludger Schuknecht and Isabel Vansteenkiste ${ }^{2}$

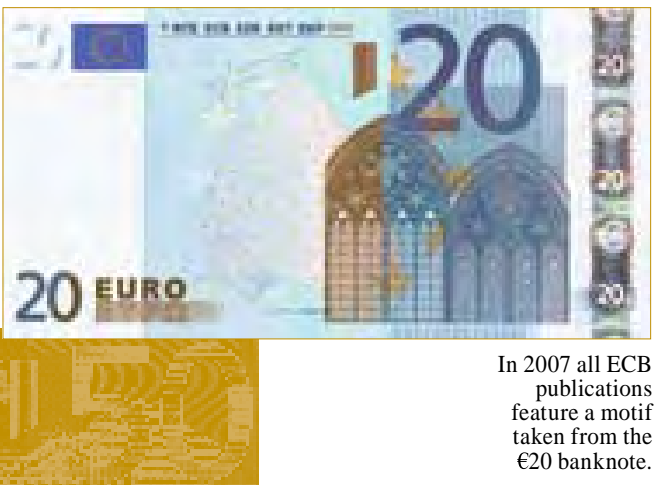

This paper can be downloaded without charge from http://www.ecb.int or from the Social Science Research Network electronic library at http://ssrn.com/abstract_id $=1015256$.

I Valuable research assistance by Gerhard Schwab, Tobias Blattner and leva Rubene and editorial support by Sarah Whitehead, Saskia Schwaegermann and Stefanie Peuckmann is most appreciated. Comments by Antonio Afonso, Marcel Fratzscher, Lars Jonung, Hans Joachim Klöckers, José Marin, Philipp Rother, Livio Stracca, Max Watson, an anonymous referee, and the participants of the Second DG ECFIN Research Conference, European Commission, Brussels 6-7 October 2005, the IMF-EUR seminar in Washington on 29 June 2006 and the DG-Economics seminar of the ECB were very helpful. The views represented are those of the authors and not necessarily those of the ECB. 
(c) European Central Bank, 2007

Address

Kaiserstrasse 29

60311 Frankfurt am Main, Germany

\section{Postal address}

Postfach 160319

60066 Frankfurt am Main, Germany

\section{Telephone}

+496913440

\section{Website}

http://www.ecb.europa.eu

\section{Fax}

+496913446000

Telex

411144 ecb d

All rights reserved.

Any reproduction, publication and reprint in the form of a differen publication, whether printed or produced electronically, in whole or in part, is permitted only with the explicit written authorisation of the ECB or the author(s).

The views expressed in this paper do not necessarily reflect those of the European Central Bank.

The statement of purpose for the ECB Working Paper Series is available from the ECB website, http://www.ecb.europa. eu/pub/scientific/wps/date/html/index. en.html

ISSN 1561-0810 (print)

ISSN 1725-2806 (online) 


\section{CONTENTS}

Abstract

Non-technical summary

1 Introduction

2 Conceptual isssues

2.1 Transmission channels

2.2 Identification of booms and busts

2.3 Internal versus external adjustment

2.4 Country and variable choice and "road map" for discussion

3 Analysing past boom-bust episodes in industrialised economies

3.1 Stylised facts on boom-bust episodes in industrialized countries in the 1980s and 90s I2

3.2 Econometric analysis

4 The Central and East European EU Member States

5 Conclusions

References

Annexes Table: Data and sources

European Central Bank Working Paper Series 


\begin{abstract}
Numerous countries have experienced boom-bust episodes in asset prices in the past 20 years. This study looks at stylised facts and conducts statistical and econometric analysis for such episodes, distinguishing between industrialised countries that experienced external adjustment (via real effective exchange rate depreciation during busts) and those that relied on an internal adjustment process (and experienced no depreciation).

The study finds that different adjustment experiences are correlated with the degree of macroeconomic imbalances and balance sheet problems. Internal adjustment seems more prevalent when financial vulnerabilities, excess demand and competitiveness loss remain relatively contained in the boom. In the bust, internal adjusters experience more protracted but less deep downturns than external adjusters as imbalances unwind more slowly.

Some Central and East European EU Member States are currently experiencing strong credit and asset price growth in conjunction with rapid economic expansion. Against this background the experience of other countries may raise awareness of related policy challenges.
\end{abstract}

Key words: Booms and busts, external and internal adjustment, exchange rates, financial imbalances, competitiveness

JEL codes: E32, E63, E65 


\section{Non-technical summary}

What have been the experiences with boom-bust episodes that have affected numerous countries over the past 20 years? What role has the exchange rate played for adjustment? These are the first questions that this study tries to answer by deriving stylised facts and conducting statistical and econometric analysis on a number of boom-bust episodes in industrialised countries.

Many of these episodes have already been studied extensively but often on a country basis. This study takes a more comprehensive view and looks at experiences and patterns across industrialised countries and compares this with the situation in a number of Central and East European (CEE) EU Member States. Moreover, the study analyses exchange rate adjustment patterns in the face of busts. It differentiates between those countries that experienced a (CPI-based) real effective exchange rate depreciation/devaluation during the bust, which we call "external adjusters", and those that did not experience a devaluation, which we call "internal adjusters".

The findings of the study support the claim that real and financial variables interact in boom-bust episodes where asset price cycles and their impact on private balance sheets constitute an important driving force. Most importantly, countries' different exchange rate adjustment experiences are correlated with the extent of macroeconomic imbalances and the degree of balance sheet vulnerability. Together with relatively loose fiscal policies, this appears to have stoked asset price and consumer price inflation and domestic demand. At the same time it reinforced competitiveness losses in the boom which - when fortunes reversed - exacerbated the bust and the resulting adjustment needs. In those cases where the exchange rate was devalued, this shift in policy first reinforced balance sheet problems in the private sector but then precipitated a rapid recovery. From this we conclude:

- External adjusters tend to experience more pronounced booms with more overheating of demand, increases in prices and credit, loss of competitiveness and deterioration of (private sector, external and public) balance sheets than reported for internal adjusters.

- In busts, external adjusters tend to experience deep downturns and rapid recoveries as imbalances are initially more severe but, subsequently, also unwind more quickly. Internal adjusters tend to face less deep but more protracted downturns (and even deflation) as imbalances unwind more slowly and adjustment via the trade and credit channels takes more time.

- Statistical and preliminary econometric analysis broadly confirms stylised facts on boom-bust episodes, with domestic and international financial variables appearing to have the most significant predictive power for the most likely pattern of exchange rate adjustment.

The study seems to confirm many "orthodox" messages:

- The more significant demand and financial excesses, competitiveness loss, and fiscal and external imbalances in the course of the boom the more likely it seems that a country would be found in the group of external adjusters in the bust.

- Internal adjustment appears to be more prevalent when external and fiscal imbalances are small, and when credit growth, inflation and competitiveness loss is contained during the boom

With regard to the CEE EU Member States, the study suggests that some of these are currently experiencing strong credit and asset price growth in conjunction with rapid economic expansion. Clear and definite conclusions regarding these countries' situation and prospects can not be drawn yet, not least due to the serious data problems that complicate inter alia a detailed examination of asset price developments and balance-sheet vulnerabilities, but also due to the difficulties associated 
with distinguishing booms from catching-up effects. In addition, the institutional framework provided by EU membership and the prospect of euro adoption - once the CEE countries fulfill the Maastricht convergence criteria - are specific to this group of countries. Nevertheless the experiences of boom-bust scenarios in other countries may raise awareness of related policy challenges in the CEE countries. 


\section{Introduction}

What have been the experiences with boom-bust episodes that have affected numerous countries over the past 20 years? What role has the exchange rate played for adjustment?

These are the first questions that this study tries to answer by deriving stylised facts on a number of boom-bust episodes. Many of these episodes have already been studied extensively but often on a country basis. This study takes a more comprehensive view and looks at experiences and patterns across different industrialised countries and compares this with the situation in a number of Central and East European (CEE) EU Member States.

Moreover, the study analyses patterns of exchange rate adjustment in the face of busts. It differentiates between those countries that experienced a (CPI-based) real effective exchange rate depreciation/devaluation during the bust, which we call "external adjusters", and those that did not experience a devaluation, which we call "internal adjusters".

The study looks at the interaction of real and financial sector variables in boom-bust episodes where asset price cycles and their impact on private balance sheets constitute an important driving force. Volatility can be reinforced (or moderated) through domestic macroeconomic factors, competitiveness developments and the international financial environment. We first derive stylised facts for different country groups by examining a number of relevant flow and stock variables. In addition, we conduct statistical and econometric analyses as regards the incidence and patterns of boom and bust episodes and the type of adjustment (external vs internal) that countries experienced.

The study finds that countries' different (exchange rate) adjustment experiences are correlated with the extent of macroeconomic imbalances and balance sheet deterioration.

- External adjusters tend to experience more pronounced booms with more overheating of demand, increases in prices and credit, loss of competitiveness and deterioration of (private, public and external) balance sheets than reported for internal adjusters.

- In busts, external adjusters tend to experience deep downturns and rapid recoveries as imbalances are initially more severe but, subsequently, also unwind more quickly. Internal adjusters tend to face less deep but more protracted downturns as imbalances unwind more slowly and adjustment via the trade and credit channels takes more time.

- Statistical and preliminary econometric analysis broadly confirms stylised facts on boom bust episodes, with domestic and international financial variables appearing to have the most significant predictive power for the role of the exchange rate in adjustment.

What is the current situation of the CEE EU Member States? The analysis of these countries suggests that some of them are currently experiencing strong credit and asset price growth in conjunction with rapid economic expansion. Clear and definite conclusions regarding these countries' situation and prospects can not be drawn yet, not least due to serious data problems as well as the difficulties associated with distinguishing booms from catching-up effects. Nevertheless the experiences of boom-bust scenarios in other countries may raise awareness of related policy challenges. ${ }^{3}$

The study has a number of shortcomings. The choice to discuss stylised facts for a relatively large number of countries comes at the expense of a more detailed analysis. Furthermore, we do not

3 In addition, with respect to the CEE EU Member States it is important to keep in mind that many boom episodes did not end in a bust period. Including such episodes and comparing them in a systematic way with the current situation in the CEE EU Member States is, however, beyond the scope of this paper. 
analyse whether countries "chose" a certain adjustment strategy or whether markets "forced" them to do so (or a mixture of the two). ${ }^{4} \mathrm{We}$ are mainly interested in detecting patterns of cross-country experiences with booms and busts as depending on the different exchange rate adjustment experience. Moreover, we focus on the interaction of various transmission channels but not on institutional and micro-structural issues. Finally, the statistical and econometric analysis presents a first attempt to underpin the stylised facts with more rigorous analysis, keeping in mind that data shortcomings and a small sample size are limiting the scope of such an analysis.

The study is organized as follows. The next section discusses conceptual issues, including the discussion of exchange rate adjustment experiences, the relevant sectoral variables and transmission channels and the methodology for identifying boom-bust cycles. Section three discusses the experience of ten industrialised countries with boom-bust phases in the 1980s-1990s including an empirical analysis. Section 4 takes stock of the situation in CEE EU Member States. Section 5 concludes.

\section{Conceptual issues}

\subsection{Transmission channels}

Boom-bust episodes are empirical phenomena. There is not just one and only one theoretical framework that defines them and explains their emergence and evolution. There are different theoretical approaches and measurement tools. Nevertheless, there is a considerable literature that looks at boom bust episodes primarily as a result of asset price "cycles" that propagate into the real economy via the credit transmission channel (Bernanke, Gertler and Gilchrist, 1999; Bordo and Jeanne, 2002; Borio, 2005). ${ }^{5}$ This channel also forms our conceptual basis for identifying boombust episodes. However, there are also three other propagation mechanisms or transmission channels which play a role in the evolution of booms and busts and which warrant a brief discussion: ii) the trade channel, iii) the international financial channel, and iv) the fiscal channel.

As regards the first channel, the financial accelerator literature explains the emergence of boombust phenomena in the real and financial economy via asset supply rigidities and the credit transmission channel. When asset prices rise, the collateral value of the assets increases which, in turn, stokes credit supply and demand. This in conjunction with wealth effects provokes further real demand, output and asset price rises. Asset supply increases and growth of debt cause this process to reverse at some point (putting pressure on prices and net worth), and the opposite, mutually reinforcing dynamics fuel the downturn of asset prices and the real economy.

The second channel worth referring to in this context is the trade channel. In a period of strong growth, a country may lose competitiveness via rising unit labour costs. This initially further boosts domestic demand and imports but it undermines the tradable goods sector and export growth. Over time the weakening effect from exports and the trade-competing sector start to dominate, employment is falling, so that growth weakens. In the downturn and especially if a devaluation of the exchange rate takes place, relative price adjustments result in the revival of import-competing industries which together with rising exports helps the economy to emerge from the downturn. If the exchange rate is not devalued, the full adjustment has to come through a reversal of unit labour costs and relative prices between tradables/non-tradables before the revival of exports and importcompeting industries can set in.

4 The "choice" of adjustment strategy is to some extent "endogenous" to the extent of prevailing imbalances as larger imbalances ceteris paribus make internal adjustment more difficult/costly.

5 A somewhat different approach where frictions from adjustment costs to investment and monopolistic competition in the non-trade goods sector can generate boom bust phenomena in dynamics general equilibrium modelling is applied by Fagan and Gaspar (2005). 
The third channel is the international financial channel. Capital inflows in the boom/high growth period keep the exchange rate appreciated and imports cheap. Sudden stops of inflows and net capital outflows can exacerbate (if not trigger) the asset price bust and downturn of the real economy by choking domestic demand, increasing pressure on the exchange rate and on the banking system (see Calvo, Izquierdo and Mejia, 2004; Calvo, Izquierdo and Talvi, 2003 or Eichengreen and Choudhry, 2005).

Much attention has been drawn to international capital flows exacerbating booms. They can give rise to significant short term and foreign-currency denominated debt, coupled with insufficient reserves. If then the boom turns to bust, a reversal of capital flows may make the exchange rate untenable which, in turn, exacerbates the effect of asset price declines on collateral value and nonperforming loans and may even push the economy from "bust" into a "full-fledged" crisis. By contrast, the opposite case of countries experiencing capital inflows and pressure on their exchange rate to appreciate during bust phases has received much less attention. We will see below that this has been the experience of a number of countries whose currencies are considered safe havens including Switzerland and Japan. In these instances, relative prices in the tradable-non-tradable goods sectors in the bust have to adjust internally even more strongly.

The role of public finances (or the fiscal channel) is little discussed in the boom-bust literature. Jaeger and Schuknecht (2004) point to revenue windfalls during booms that derive from asset-based taxes and from indirect tax revenue that is boosted by wealth effects on domestic demand. These windfalls can be very significant. They can create incentives of pro-cyclical policies in the boom if such windfalls are not recognized as such and spent. Fiscal policies can also be (forced to become) pro-cyclical in the downturn if the fiscal position at the beginning of the bust is weak and adjustment is needed to prevent destabilizing deficit increases. Jaeger and Schuknecht find significant evidence for such pro-cyclical policies in a study of industrialised country boom-bust episodes since the 1970 s.

Fiscal policies can also exacerbate boom-bust experiences via indirect effects through other channels. The financing needs arising from large fiscal deficits can increase vulnerability via the international financial channel if such deficits raise the current account deficit and hence the vulnerability to "sudden stops". Fiscal policies can worsen imbalances via the competitiveness/trade and domestic financial channels if public wage and employment increases put pressure on unit labour costs and if these, in turn, stoke credit and asset price booms.

The previous references to interlinkages between the sectoral channels, already point to the fact that vulnerabilities and risks need to be assessed from an inter-sectoral perspective. Or in other words, we need to look at systemic risks and not just at sectoral ones. The literature has started to acknowledge the importance of analysing intersectoral linkages, especially via balance sheet vulnerability (Allen, Rosenberg, Keller, Setser and Roubini (2002). Boom-bust phenomena that in some cases culminate in financial/BOP crises are intellectually interesting because of these very complexities. Moreover, they are economically relevant because of the significant adjustment needs and the large output and fiscal costs that can arise in protracted busts or deep crises (Watson, 2005; Honohan and Klingebiel, 2003; Bordo and Jeanne, 2002; Calvo et al).

\subsection{Identification of booms and busts}

But when is there a boom and bust? There is by now a considerable literature that develops methodologies of identifying such phenomena. These include Bordo and Jeanne (2002), Jaeger and Schuknecht (2004), or Detken and Smets (2004) for defining boom and bust episodes in industrialized countries.

In this study, we look at (i) boom-bust episodes in industrialised countries since the mid 1980s as identified in Jaeger and Schuknecht, 2004 and defined as phases of major and persistent upswings 
or downturns in asset price indices as derived by Borio, Kennedy and Prowse (1994) and (ii) the situation of the CEE EU Member States, where in some cases strong growth is also coupled with anecdotal evidence of very significant asset price increases.

Jaeger and Schuknecht (2004) construct boom and bust phases in real asset prices by following a dating method initially proposed by Harding and Pagan (2002), based on the so-called triangular methodology. This technique identifies the peaks and troughs of the asset price series (their turning points) whereby asset price indicators include stocks and real estate depending on their weight in the asset composition of an economy. They then calculate the duration of the period from trough to peak (the upswing) and from peak to trough (the downturn) and the amplitude of the asset price changes over these periods. By multiplying duration and amplitude, they arrive at a ranking of asset price upswings and downturns of which the largest quintile is referred to as boom-bust episodes. This enables them to separate booms and busts in asset prices from more normal asset price movements. The approach does not entail that a boom or a bust phase needs to be followed by another similar phase.

This analysis is based on asset price data generated on the basis of the methodology described in Borio, Kennedy and Prowse (1994). The relevant asset prices are real estate and stock prices from which a composite indicator is generated by splicing the series according to the relative value of housing and stock markets. ${ }^{6}$

\subsection{Internal versus external adjustment}

When countries need to adjust in an environment turning from boom to bust as discussed above, they can either adjust through the exchange rate or the domestic price level or a combination of both. In this study we refer to external adjusters as those countries that saw the nominal exchange rate depreciate and (due to inflation differentials with trading partners being smaller than the devaluation) also experienced a depreciation of the real effective exchange rate. Internal adjusters are those countries that did not allow a depreciation or that experienced an appreciation of their real exchange rate through the depreciation of their trading partners. These countries had to correct real wage or tradable/non tradable sector imbalances via domestic price adjustments while external adjusters primarily (though not necessarily exclusively) addressed imbalances through the exchange rate change.

We measure exchange rate developments via the real effective exchange rate that adjusts nominal exchange rate changes for CPI differentials for the weighted average of trading partners. This is a more appropriate measure than unit labour cost-based measures which already include wage-based internal adjustment.

\subsection{Country and variable choice and "road map" for discussion}

Table 1 presents the countries we examine, the periods of booms and busts and the respective adjustment experience of each country. We initially apply a so-called case study approach. For all countries the first year of the bust are set as t1. Previous years cover the boom period and are counted backward. Following years cover the bust period. We normally look at 12 year windows from $\mathrm{t}-6$ to $\mathrm{t} 5$ (unless $\mathrm{t} 1$ is so recent that data until t5 is not yet available). We also conduct Wilcoxon/Mann-Whitney tests to see whether differences in the means and variances of external and internal adjusters are "significant" and subsequently pursue an econometric analysis.

\footnotetext{
${ }^{6}$ See Chart A3 for real estate prices in industrialized countries during the sample period.
} 
Table 1: Sample countries and relevant dates/episodes

\begin{tabular}{|lcc|}
\hline Country & Boom & Bust \\
\hline I. Industrialised countries, mid 1980s - early 1990s & & \\
"External adjusters" & $1984-89$ & $1990-95$ \\
Australia & $1985-89$ & $1990-95$ \\
Canada & $1986-89$ & $1990-93$ \\
Finland & & $1991-97$ \\
Italy & $1985-90$ & $1991-95$ \\
Spain & $1986-89$ & $1990-93$ \\
Sweden & $1983-89$ & $1990-94$ \\
United Kingdom & $1986-90$ & $1991-96$ \\
"Internal adjusters" & $1979-90$ & $1991-02$ \\
France & $1983-89$ & $1990-96$ \\
Japan & & Observation period \\
Switzerland & All 1999-2006 \\
II. Central and East European EU Member States & \\
Bulgaria & & \\
Czech Republic & & \\
Estonia & & \\
Hungary & & \\
Latvia & & \\
Lithuania & & \\
Poland & & \\
Romania & & \\
Slovakia & & \\
\hline
\end{tabular}

We look at a number of stock and flow variables that are most representative of the economic sectors and transmission channels discussed above. As shown in table 2, these include (i) output and demand related variables, (ii) credit and asset price variables and private sector debt (domestic financial channel), (iii) real effective exchange rate, unit labour costs and export/GDP (trade/competitiveness channel), (iv) the current account and external financing patterns and external debt (international financial channel) and (v) public deficits and debt (fiscal channel). As will be seen, this matrix of variables can in reality not be discussed fully homogenously as there are significant data gaps. But it provides a road map linking the conceptual framework with the quantitative analysis below.

Table 2: Sample countries and relevant dates/episodes

\begin{tabular}{|l|l|l|l|l|l|}
\hline & $\begin{array}{l}\text { Real (demand } \\
\text { and supply) }\end{array}$ & $\begin{array}{l}\text { Domestic } \\
\text { financial }\end{array}$ & $\begin{array}{l}\text { Trade/external } \\
\text { competitiveness }\end{array}$ & $\begin{array}{l}\text { International } \\
\text { financial }\end{array}$ & Fiscal \\
\hline $\begin{array}{l}\text { Flow } \\
\text { variables }\end{array}$ & $\begin{array}{l}\Delta \text { output/ } \\
\text { consumption/ } \\
\text { investment }\end{array}$ & $\begin{array}{l}\Delta \text { credit } \\
\Delta \text { asset } \\
\text { prices }\end{array}$ & $\begin{array}{l}\Delta \text { real effective } \\
\text { exchange rate/ } \\
\text { unit labour } \\
\text { costs/ } \\
\text { exports/current } \\
\text { account }\end{array}$ & $\begin{array}{l}\text { External } \\
\text { financing via } \\
\text { FDI, portfolio } \\
\text { and other inv. }\end{array}$ & Deficit \\
\hline $\begin{array}{l}\text { Stock } \\
\text { variables }\end{array}$ & $\begin{array}{l}\text { Cumulative } \\
\text { changes }\end{array}$ & $\begin{array}{l}\text { Household } \\
\text { \& corporate } \\
\text { debt }\end{array}$ & $\begin{array}{l}\text { Cumulative } \\
\text { changes }\end{array}$ & $\begin{array}{l}\text { Cumulative } \\
\text { changes }\end{array}$ & $\begin{array}{l}\text { Public } \\
\text { debt }\end{array}$ \\
\hline
\end{tabular}


As we put particular emphasis on exchange rate developments and related adjustment experiences, we will first distinguish external and internal adjusters according to their real effective exchange rate developments. The subsequent discussion starts from the presumption of a certain sequencing in boom-bust episodes that also suggests a certain order of the sectoral discussion. Initially domestic financial and real variables seem to interact and produce a boom. We start with the discussion of real sector variables before proceeding to asset prices and domestic financial developments. ${ }^{7}$

The trade and competitiveness channel tends to contribute to ending the boom and is therefore discussed thereafter. The international financial channel can already exacerbate the boom but since its greater relevance is for emerging markets and new member countries it is discussed fourth. Although public finances can exacerbate or moderate boom-bust episodes, the government often picks up the tap (as losses are socialized) and, hence, this channel is discussed last.

\section{Analysing past boom-bust episodes in industrialised economies}

\subsection{Stylised facts on boom-bust episodes in industrialized countries in the 1980s and 90s}

This section will look at case studies and stylised facts for 10 industrialised country which experienced (asset price) boom-bust episodes in the late 1980s and 1990s. ${ }^{8}$ As we are particularly interested in the external environment and exchange rate policies, we will present stylised facts for 1) the seven countries that experienced a depreciation of their real effective exchange rate in the bust. They include the UK, Sweden, Finland, Australia, Canada, Italy and Spain. These external adjusters are mostly countries that had relatively fixed exchange rates in the boom but floated/devalued their currencies early in the bust. 2) The three countries that experienced an appreciation in the real effective exchange rate (CPI-based) in the bust. This group includes Japan, Switzerland and France (called internal adjusters). Two of the internal adjusters had floating currencies throughout the boom and bust (Japan and Switzerland). France maintained its peg to the DM (while widening the band) so that it experienced a relative appreciation as its main trading partners devalued.

To prepare the discussion of stylised facts across economic sectors from the angle proposed above, we look at exchange rate developments in the sample countries. Chart A1 shows that over the boom period, the ten countries experienced a (CPI-based) real effective exchange rate appreciation (REER) by roughly $10 \%$ on average. This appreciation was more pronounced in the group of external adjusters, especially towards the end of the boom. Most interesting is the pattern during the bust: external adjusters show a strong depreciation in the REER as of the second/third year of the bust (when most sample countries actively devalued or floated their currencies). A continued, gradual appreciation was experienced by the internal adjusters.

As regards the real economic environment, Chart A2 shows the relatively strong growth performance in the boom of the late 1980s (t-5 to t0): three to four percent real growth. In the bust (t1-t6), growth not only fell rapidly but significant divergences across the two countries groups emerged. Amongst external adjusters growth fell very rapidly. Growth on average was negative by t2. This was followed by a sharp rebound in t3-t4. Internal adjusters experienced a more gradual slowdown to near zero growth in $\mathrm{t} 2$ and $\mathrm{t} 3$. But the subsequent recovery was also much more

7 The reverse order is also conceivable (see e.g. Jonung, Schuknecht and Tujula, 2005) given that this is something of a "chicken and egg problem". However, the more "conventional" ordering approach chosen in this study appeared to be a bit more reader-friendly.

8 For earlier studies, applying a stylised facts approach on these phenomena see also Jaeger and Schuknecht (2004), Jonung, Schuknecht and Tujula (2005), and IMF (2000). 
gradual: average growth only recovered to $1-2 \%$ by the end of the observation period. In more concrete terms, it reflects the experience of six years of very low growth in France and Switzerland and the very persistent weak growth performance of Japan.

Turning to demand composition, all countries experienced a strong consumption and investment boom where average growth rates exceeded output growth (hence contributing to growing external imbalances). In the bust, the picture reversed with the result that cumulative positive departures from trend consumption and investment were balanced out or even overshot in the other direction in the bust. ${ }^{9}$ Consumption and investment declines were even steeper in the group of external adjusters, in line with the picture for real output growth.

Turning to the domestic financial environment, Chart A3 illustrates the significant real estate price cycle that was experienced over the boom and bust phase across all countries. Note that price increases during the boom were somewhat more extreme for external as compared to internal adjusters. The real estate price cycle coincided with a distinct credit cycle where credit growth accelerated gradually until the end of the boom phase and decelerated sharply thereafter (Chart A4). The credit cycle was also more pronounced for the external adjusters.

The credit and real estate boom led to a considerable build up of private sector debt in the boom that was (at least partly) reversed in the bust. However, good quality data for that period is only available for very few countries. Household and corporate debt ratios increased on average by $50 \%$ during the boom. This increase was largest in Japan (from 140\% of GDP in 1980 to about $210 \%$ of GDP in 1991). On the whole, this picture is consistent with the view that the asset price cycle in conjunction with the credit channel contributed to the emergence and evolution of boom-bust phases.

9 Jaeger and Schuknecht (2004) found that the average cumulative deviation from trend in booms and busts amounted to about $10 \%$ for consumption and about one quarter for investment. 

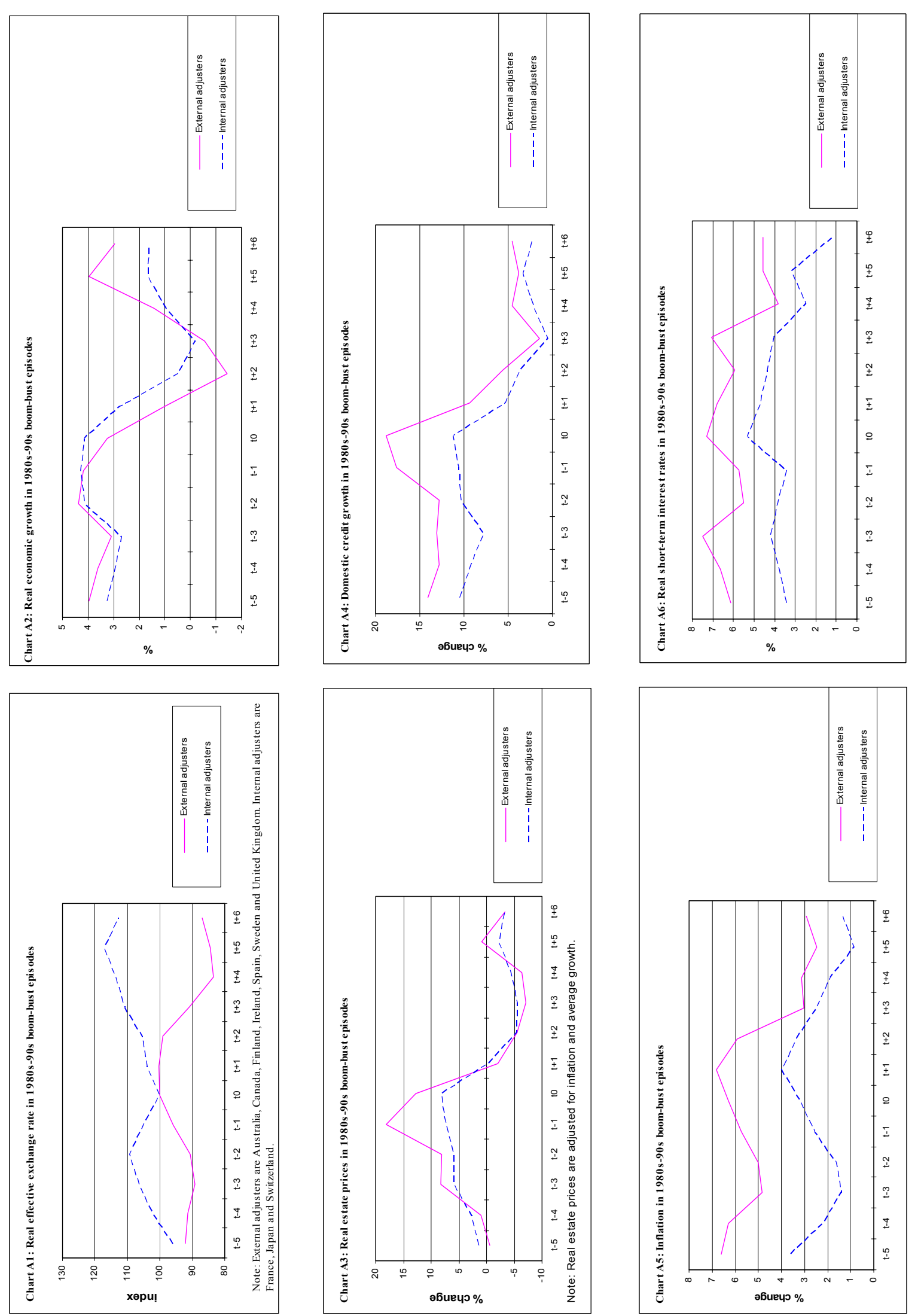

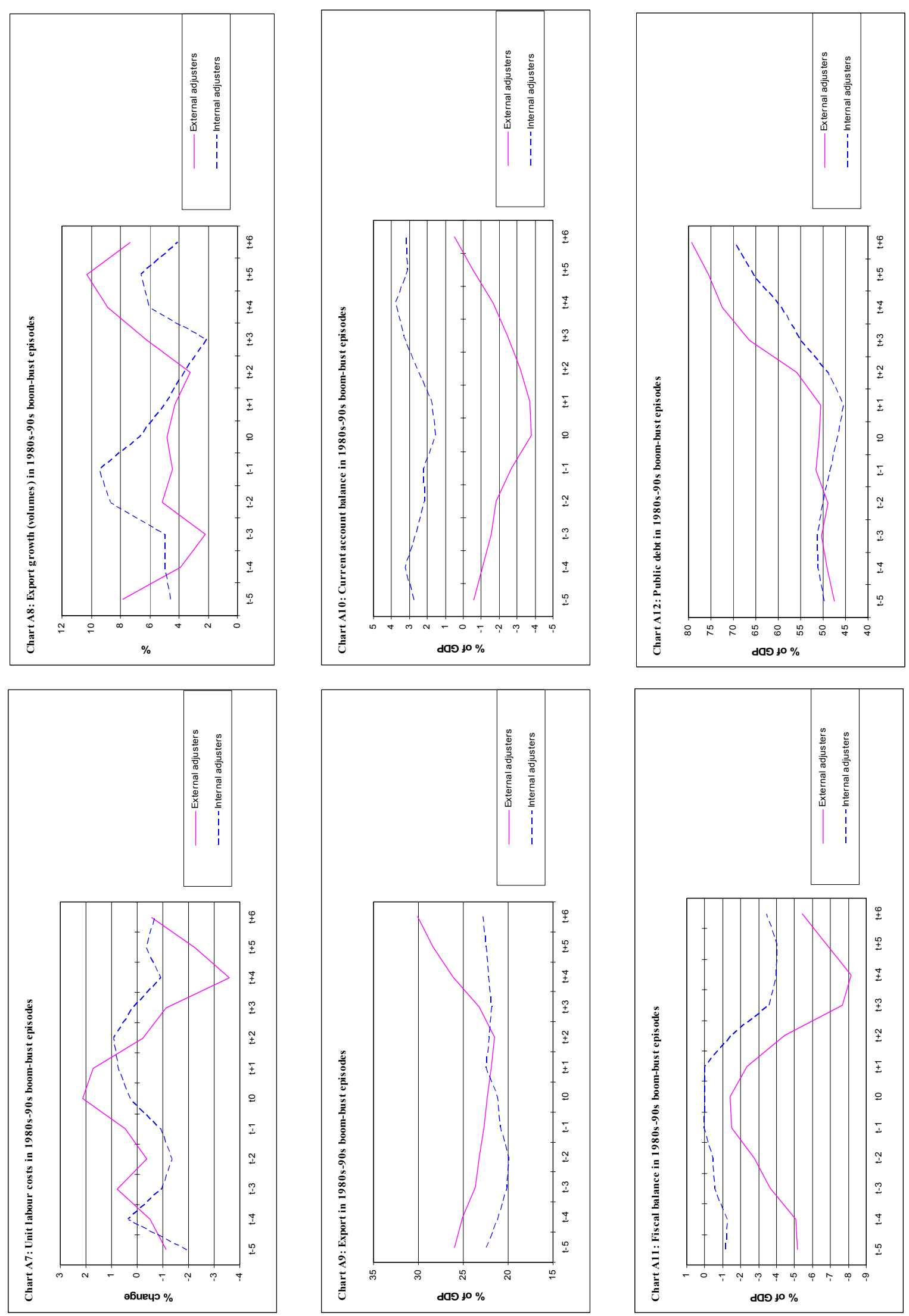
Inflation developments are also interesting and point to important problems in the policy mix for external adjusters (Chart A5). On the whole, inflation picked up rather gradually over the boom before declining in the downturn. But as regards the two country groups, external adjusters on average experienced significantly higher inflation than internal adjusters in the boom. While inflation differentials were relatively moderate on a year-to-year basis (inflation peaked in $\mathrm{t} 1 \mathrm{at} 7 \%$ for the average of external adjusters versus $4 \%$ for internal adjusters) the differential accumulated over the years is nevertheless very significant. In the bust, external adjusters experienced continued inflation pressures partly as a result of significant exchange rate devaluations.

The different inflation performance in conjunction with the credit channel could be an explanation for the hammock-shaped pattern of protracted low growth experienced by internal adjusters during the bust that contrasts with the $\mathrm{V}$-shaped pattern experienced by external adjusters. The high inflation rate of the external adjusters facilitated a rapid price adjustment in real estate markets without much of a nominal price fall (given that real estate prices tend to be nominally sticky). Low inflation countries, by contrast, experienced a much more protracted housing market adjustment. The adverse effects of drawn-out house price adjustments via collateral effects on credit markets were, therefore, probably less pronounced but more persistent than in high inflation countries.

Interest rate policies at the time of the boom reflect the fact that external adjusters' monetary policies were geared at exchange rate targeting where high capital inflows kept interest rates less counter-cyclical than the strong demand (and asset price) boom might have otherwise suggested. Initially, interest rates also stayed high during the bust, first to defend the exchange rate and subsequently to fight inflationary pressures (Chart A6). Internal adjusters pursued somewhat more counter-cyclical policies and real interest rates rose more strongly in the boom while coming down gradually in the bust.

Turning to competitiveness and the trade channel, we find a strong divergence in competitiveness and trade developments over time and across country groups. We start with unit labour costs (ULC) which followed a very similar pattern as real and financial variables did before with ULC growth increasing over the boom before declining significantly in the bust (Chart A7). The internal adjusters experienced a much more gradual trend of unit labour cost increases and decreases. External adjusters, however, first experienced significant ULC increase before experiencing a rather sharp reversal.

Real effective exchange rates and unit labour costs together are probably largely responsible for the emerging pattern of trade developments and, hence, the role of the trade channel. External adjusters experienced much weaker export growth than internal adjusters over the boom period (Chart A8). In the bust this relation reversed. Export volume growth increased strongly in the context of depreciation/devaluation while it remained more muted in countries pursuing internal adjustment. As a result export/GDP ratios were roughly flat over the boom and bust cycle for internal adjusters (Chart A9). For external adjusters, this ratio first declined in the boom before rising again in the bust. This supports the claim that competitiveness changes and the trade channel were much less relevant in the case of internal adjusters. This may be the second (and perhaps even more important) reason why the growth profile during the bust is that of protracted low growth (hammock) for internal adjusters than that of deep downturn followed by a rapid recovery (V shaped) for external adjusters.

Pulling the information from the real and external side together, we should find - and indeed this is confirmed in Chart A10 - that the current account balance (the counterpart to domestic savings and investment balance) deteriorates for the average of all countries in the boom before improving in the bust. This pattern is more distinct for external adjusters in the boom and bust due to stronger domestic demand growth in excess of output growth and competitiveness loss, slower export growth in the boom and a more distinct reversal of these trends in the bust. As regards the level of the current account balance, external adjusters on average report a deficit over the full cycle which increases 
strongly over the boom. Internal adjusters show a very modest deterioration in the current account in the boom and a moderate improvement in the bust and overall levels remain positive throughout the cycle.

The international financial channel at first seems less relevant for this sample of countries where the volatility of capital flows is normally assumed to play a lesser role. Nevertheless given significant current account deficits in one group, the pattern of "other investment flows" (bank lending etc) for this group is worth looking at. The literature has identified exposure to short term foreign capital as a main vulnerability that could lead to abrupt adjustment needs in periods of confidence loss ("sudden stops"). External adjusters experienced strong inflows in the boom (up to $3 \%$ of GDP per annum) and strong outflows over the first three years of the bust (also up to almost $3 \%$ of GDP). In this particular instance it is also worthwhile looking at individual countries in this group. The clearest sign of emerging market type "sudden stop" phenomena is visible for Finland and in particular Sweden. In the latter case, inflows of other investment amounted to $12.2 \%$ of GDP in 1990 before reversing to $-2.7 \%$ in 1991 and staying negative until 1993. In these cases, anecdotal evidence also points to strong exposure to foreign-currency denominated debt in the private sector but firm data is hard to come by.

What role did fiscal policies play? First, fiscal variables reflect the revenue impact of the boom bust cycle where revenue windfalls from capital gains related taxes boost fiscal accounts in the boom before reversing in the downturn. Consequently, the fiscal balance improves over the boom before deteriorating strongly over the bust (Chart A11). Again there is a difference in magnitude and levels in parallel with current account developments: internal adjusters experience better fiscal balances and a slower deterioration of fiscal accounts than external adjusters. The data also replicates the findings of Jaeger and Schuknecht (2004) who argue that political economy dynamics induce insufficient consolidation in the boom (the windfall is spent) and result in significant average deficits over the boom-bust cycles. In some (but not all) cases deficits reached magnitudes that required pro-cyclical consolidation to avoid macroeconomic destabilization.

The pattern of deficits and growth over boom bust cycles determine public debt developments: debt goes down modestly in the boom before rising rapidly in the bust (Chart A12). Another way of interpreting this result is that the benefits of the boom are largely "privatized" while the costs are "socialized". In some cases, this socialization was rather direct through bank and balance sheet support, e.g., in the cases of Sweden and Finland (Jonung and Stymne, 1997; Eschenbach and Schuknecht, 2004). In these countries, debt increased by 30 and 50\% of GDP respectively.

While the Chart illustrates well the sustainability risks from boom-bust episodes for external adjusters, it perhaps underemphasizes this risk for internal adjusters. Internal adjusters' debt dynamics look healthier at first but they also become very adverse over time and continue to remain adverse for longer as the adjustment period is more prolonged. Japan is the most extreme case in point.

Some simple statistical tests support the evidence as regards differences in the means and patterns over boom-bust episodes across the two country groups for most of the variables discussed above. Table 3 shows the results for Wilcoxon/Mann-Whitney tests for differences in the means of the two country groups ("populations") and tests of equal Variance (F-tests) for differences in the volatility of the series. ${ }^{10}$ Real effective exchange rates, credit, inflation, export shares and fiscal and external balances are found to differ significantly between internal and external adjusters. As regards real GDP and export growth, differences in means and volatility are not confirmed. This suggests that the main difference between the two groups is not the level and extremeness of the business and trade cycle per se while the more accentuated downturns and upswings in the groups of external adjusters is not picked up well with this test. The equal variance test finds a significant

${ }^{10}$ The test is performed taken the average of each variable for the country groups over the period 19841995. Results in Table 3 show the p-value of the test. 
difference in the amplitude of swings for the export share and the current account balance and perhaps even more importantly, for unit labour costs and (not quite statistically significant) real estate prices.

Table 3: Wilcoxon signed ranks test for selected indicators, boom-bust episodes in industrialised countries in the 1980s and 1990s

\begin{tabular}{|l|c|c|}
\hline & $\begin{array}{c}\text { Median (Wilcoxon/Mann- } \\
\text { Whitney) }\end{array}$ & $\begin{array}{c}\text { Eq. Variance } \\
\text { (F-test) }\end{array}$ \\
\hline REER & \multicolumn{2}{|c|}{ P-value } \\
\hline Real GDP growth & $\mathbf{0 . 0 8}^{*}$ & 0.62 \\
\hline Real estate prices & 0.62 & 0.40 \\
\hline Domestic credit growth & 0.84 & 0.14 \\
\hline Inflation & $\mathbf{0 . 0 9}^{*}$ & 0.22 \\
\hline ULC & $\mathbf{0 . 0 0}^{* * * *}$ & 0.77 \\
\hline Export growth (volumes) & 0.89 & $\mathbf{0 . 0 6}$ \\
\hline Export (\% of GDP) & 0.98 & 0.61 \\
\hline Current account balance, \% of GDP & $\mathbf{0 . 0 0 2}^{* * * *}$ & $\mathbf{0 . 0 0 2}$ \\
\hline Fiscal balance, \% of GDP & $\mathbf{0 . 0 0}^{* * * *}$ & $\mathbf{0 . 0 3}$ \\
\hline Public debt, \% of GDP & $\mathbf{0 . 0 0 3}^{* * *}$ & 0.29 \\
\hline Interest rate & 0.26 & 0.16 \\
\hline \multicolumn{2}{|c|}{ Note: $* * * * * *$ denotes significance at $1 \%, 5 \%$ and $10 \%$ significance levels. Each series has 12 observations. } \\
\hline
\end{tabular}

In summary, these stylised facts and statistical tests confirm the hypotheses expressed above: the domestic financial, trade and fiscal channels seem to contribute to the evolution of boom-bust episodes. Countries on average depicted the expected pattern of economic and financial developments. However, external adjusters were prone to experience more pronounced upswings with stronger asset price and credit growth, more competitiveness loss and unfavourable trade developments, external vulnerability due to cumulative external imbalances, and less favourable fiscal positions. In the bust, external adjusters experienced more pronounced troughs as competitiveness loss and balance sheet problems depressed demand. But once the currency was floated/devalued, growth also recovered more swiftly and forcefully, as exports rose and imports were being replaced by domestic output. The group of internal adjusters experienced fewer and smaller macroeconomic imbalances at the end of the boom and economic and financial developments were less volatile. However, internal adjustment implied a more prolonged real and financial downturn.

While the findings clearly illustrate the intersectoral linkages that are at work, it is also important to point to systemic risks that can arise from their interplay. In Sweden, Finland and Japan, busts turned into financial crisis and both groups of countries were affected. Sweden and Finland also faced emerging market-type reversals of capital flows. They floated their currencies as part of the crisis resolution strategy. This strategy reinforced immediate adjustment needs in the real and financial sectors but also facilitated the emergence from the bust. Internal adjustment, pursued by Japan, did not prevent crisis but its emergence was delayed and its impact was felt in a more protracted manner.

\subsection{Econometric analysis}

In this section we conduct an econometric analysis to underpin the stylised facts and statistical analysis on boom and bust periods presented above. In a first step, we analyse empirically the macroeconomic patterns that coincide with the incidence of booms and busts. For this purpose we use a panel probit analysis where the incidence of a boom or bust is the dependent variable and a number of macroeconomic variables reflecting the five transmission channels explained in section 2 constitute the independent variables. In more detail, the estimated model takes the form:

$$
\operatorname{Pr} o b\left(y_{i t}=1 \mid x_{t}, \beta_{t}\right)=F\left(x_{t}, \beta_{t}\right)
$$


where $x_{t}$ corresponds to our set of macroeconomic variables reflecting the five transmission channels and $\beta_{t}$ is a vector of unknown parameters. The observed variable $y_{i t}$ receives a value of 0 or 1 depending on whether a boom/bust has occurred or not. ${ }^{11}$ With a probit model, the right-hand side of the model is constrained between 0 and 1 , and is compared to the observed value $y_{i t}$. The probit model assumes that the probability distribution function $\left(y_{i t}\right.$ conditional on $\left.x_{t}\right)$ corresponds to a normal distribution.

In total, the analysis is conducted on a sample of 20 countries. As for external adjusters the sample contains: Belgium, Germany, New Zealand, Norway, Australia, Canada, Finland, Italy, Spain, Sweden and the United Kingdom. As regards the internal adjusters we use: Austria, Denmark, Greece, Ireland, Portugal, the United States, France, Japan and Switzerland. Note that the sample of countries in the empirical analysis is larger than presented in Table 1 (which contains all the countries included in the descriptive analysis). The main reason for expanding the sample is to increase the degrees of freedom in the model. The selection procedure for the additional countries is the same as those for the countries in the descriptive analysis (both for the definition of internal/external adjuster as well as the classification of boom and bust episodes). ${ }^{12}$

In a second step, we go more deeply into the factors that determine whether, in a bust, a country becomes an external or internal adjuster. For this purpose we rely on a probit cross-sectional analysis of the countries as mentioned above. The dependent variable takes in this case the value 1 if the country was an external adjuster in the bust and 0 otherwise. The independent variables consist of the same financial and macroeconomic variables that were seen as interacting in the emergence of booms and busts. We took the average of the last three years preceding the bust for these variables to test whether the effect of developments in the boom affected the probability of being an external versus internal adjuster in the bust.

The results of the first part of the analysis, namely the panel probit analysis on boom bust patterns, are presented in Table 4 which shows two models each for estimating the incidence of booms and busts. The "boom" models find that a number of macroeconomic variables related to most of the five transmission channels discussed above are significant to explain the incidence of booms. In addition, some control variables turn out to be significant as well. ${ }^{13}$

More specifically, the models suggest that strong private investment growth and a positive current account balance coincide with the incidence of a boom one or two periods later. In addition, low real interest rates, a low degree of financial depth and a high degree of trade openness increase the likelihood of a boom. Favourable public deficit figures (a budget surplus and low public debt) also appear to be positively correlated with the incidence of a boom in the ensuing period. This, however, is more likely to be a side-effect of buoyant growth rather than any causal link. The bottom part of Tables 4 reveals that the percentage of booms correctly predicted by the models is very high ( 94 and $81 \%$ respectively). By contrast, the number of periods identified as booms which were not booms is relatively low ( 35 and $25 \%$ respectively).

\footnotetext{
${ }^{11}$ In case of the boom model, all non-boom periods receive a value of 0 . In case of the bust model, all nonbust periods receive a value of 0 .

${ }^{12}$ The added countries were not included in the descriptive analysis in Section 3.1. Either the boom period was not immediately followed by a bust for these countries or the countries only experienced a boom or a bust over the sample period considered. For the added countries, the following boom and bust episodes were detected: Austria (bust: 98-02), Belgium (bust: 80-85), Germany (boom: 87-93, bust: 95-05), Ireland (boom: 94-01), the Netherlands (boom: 93-00), Norway (boom: 83-86/92-97), US (boom: 95-99, bust: 01-02), New Zealand (bust: 89-91, boom: 92-97), Greece (boom: 94-05), Portugal (bust: 90-92, boom: 96-99).

13 Most explanatory variables enter the probit model with a lag, hence avoiding the problem of endogeneity. In two cases, the variables enter contemporaneously. This is the case of fiscal balances and trade openness. However for these variables the endogeneity problem may be limited.
} 
When looking at the incidence of busts (models 3-4 of Table 4), the results of the probit estimates suggest that higher real interest rates, high unit labour cost growth, outflows of "other (international) investments" and current account deficits indicate a higher probability of a bust in the ensuing period. Trade openness is negatively correlated with the probability of a bust. Turning to fiscal policy, large public deficits and a higher level of public debt appear to precede the incidence of busts in a significant manner. The models do not predict the incidence of busts as well as that of booms, with only 67 and 55\% respectively of all bust episodes correctly anticipated. The number of periods falsely identified as busts is, however, also rather low ( 28 and 18\% respectively).

Table 4: Probit model of booms and busts - coefficient estimates

\begin{tabular}{|c|c|c|c|c|}
\hline & \multicolumn{2}{|c|}{ Dependent variable: incidence of boom } & \multicolumn{2}{|c|}{ Dependent variable: incidence of bust } \\
\hline & Model 1 & Model 2 & Model 3 & Model 4 \\
\hline \multicolumn{5}{|l|}{ Independent variables } \\
\hline \multicolumn{5}{|l|}{ Credit channel } \\
\hline Real interest rate $(-2 /-1 /-1 /-1)$ & $-0.12(-3.72)^{* * *}$ & $-0.01(-6.18)^{* *}$ & $0.14(4.33)^{* *}$ & $0.09(2.96)^{* *}$ \\
\hline \multicolumn{5}{|l|}{ Trade channel } \\
\hline Unit labour costs $(-1 /-1 /-1)$ & $-0.01(-2.19)^{* *}$ & $-0.00(-0.11)$ & $0.01(2.42)^{* *}$ & \\
\hline Inflation (-1) & & & & $0.01(1.59)$ \\
\hline \multicolumn{5}{|l|}{ Int. financial channel } \\
\hline Other investment flows $(-1 /-1)$ & $-0.00(-0.88)$ & & $-0.01(-2.37)^{* *}$ & \\
\hline \multicolumn{5}{|l|}{ Demand channel } \\
\hline Cumulative private consumption growth (-1) & $-0.08(-1.60)$ & & & \\
\hline Cumulative private investment growth $(-1 /-1)$ & $0.02(3.42)^{* *}$ & $0.01(1.91)^{* *}$ & & \\
\hline Current account balance $(-2 /-1 /-1 /-1)$ & $0.01(0.37)$ & $0.03(2.09)^{* *}$ & $-0.11(-3.67)^{* * *}$ & $-0.12(-3.92)^{* *}$ \\
\hline \multicolumn{5}{|l|}{ Fiscal balance } \\
\hline Fiscal balances $(0 / 0 / 0 / 0)$ & $0.04(1.71)^{*}$ & $0.10(3.72)^{* * *}$ & $-0.03(-2.20)^{* *}$ & $-0.6(-2.2)^{* *}$ \\
\hline Public debt $(-1 /-1 /-1 /-1)$ & $-0.03(-5.63)^{* *}$ & $-0.02(-4.21)^{* *}$ & $0.01(3.51)^{* *}$ & $0.01(1.81)^{* *}$ \\
\hline \multicolumn{5}{|l|}{ Other control variables } \\
\hline Financial depth (credit/GDP) (-2/-2/-1/-1) & $-0.01(-6.60)^{* *}$ & $-0.03(-8.0)^{* *}$ & $0.00(1.68)^{* *}$ & $0.00(4.45)^{* *}$ \\
\hline Trade openness $(0 / 0 / 0 / 0)$ & $0.00(2.69)^{* *}$ & $0.01(1.79)^{* *}$ & $-0.02(-3.92)^{* * *}$ & $-0.02(-4.07)^{* *}$ \\
\hline Constant & $3.23(5.54)^{* *}$ & $4.46(6.60)^{* *}$ & $-2.07(-4.94)^{* *}$ & $-1.27(-2.78)^{* *}$ \\
\hline $\mathrm{R}^{2}$ & 95 & 97 & 98 & 99 \\
\hline & & & & \\
\hline Booms/busts correctly anticipated & $94 \%$ & $81 \%$ & $67 \%$ & $55 \%$ \\
\hline Booms/Busts incorrectly anticipated & $35 \%$ & $25 \%$ & $28 \%$ & $18 \%$ \\
\hline
\end{tabular}

significance at $90 / 95 \%$ level. Note that the numbers between brackets show the lags introduced of the right-hand side variables.

In a next step - as mentioned above - we consider the factors that determine whether a country becomes either an external or internal adjuster. A range of determinants are considered, analogous to those used in the first analysis. The overall findings are presented in Tables 5 and 6 . Table 5 shows the general results for the various determinants we considered (ranging from fiscal variables to domestic and external variables). Table 6 then presents the results from selected regressions which turned out to have the "best" predictive power for the exchange rate adjustment experience. Given the limited degrees of freedom we first present regressions with at least one variable from each transmission channel (models 1 and 2 ) before moving to more parsimonious models including the most robust variables only (models 3 and 4 ). 
Table 5: Main regression result findings

\begin{tabular}{|c|c|c|}
\hline Variable & Sign coefficient & Significance \\
\hline \multicolumn{3}{|c|}{$\begin{array}{l}\text { Dependent variable: exchange rate adjustment experience } \\
\text { External adjustment }=1 \text {, internal adjustment }=0\end{array}$} \\
\hline \multicolumn{3}{|l|}{ Demand channel } \\
\hline $\begin{array}{l}\text { Growth } \\
\text { Investment }\end{array}$ & $\begin{array}{l}\text { Switches sign } \\
\text { Negative }\end{array}$ & $\begin{array}{l}\text { Not always } \\
\text { Not always }\end{array}$ \\
\hline \multicolumn{3}{|l|}{ Trade channel } \\
\hline $\begin{array}{l}\text { CPI inflation } \\
\text { Unit labour cost }\end{array}$ & $\begin{array}{l}\text { Positive } \\
\text { Switches sign }\end{array}$ & $\begin{array}{l}\text { Not always } \\
\text { Not always }\end{array}$ \\
\hline \multicolumn{3}{|l|}{ Credit channel } \\
\hline $\begin{array}{l}\text { Interest rate } \\
\text { Credit growth }\end{array}$ & $\begin{array}{l}\text { Positive } \\
\text { Positive }\end{array}$ & $\begin{array}{l}\text { Always } \\
\text { Always }\end{array}$ \\
\hline \multicolumn{3}{|l|}{ International financial channel } \\
\hline Other portfolio investment & Positive & Always \\
\hline Current account & Negative & Always \\
\hline \multicolumn{3}{|l|}{ Fiscal Variables } \\
\hline Fiscal balance & Negative & Not always \\
\hline Public debt & Switches sign & Never \\
\hline \multicolumn{3}{|l|}{ Control variables } \\
\hline Total openness & Positive & Always \\
\hline
\end{tabular}

Note: Not all variables can be estimated simultaneously in the regression due to the low number of observations. The results are presented at the $90 \%$ significance level.

Several results can be derived from the two tables which broadly confirm the earlier analysis of stylised facts and the Wilcoxon/Mann-Whitney tests). Robust results were obtained for the credit channel and external variables. Indeed, both credit growth and interest rates are always significant and the regression results suggest that stronger credit growth and higher real interest rates increase the likelihood that the country goes through an external adjustment during a bust. This likelihood also increases with stronger other portfolio investment flows (as a \% of the nation's GDP) or with a higher current account deficit. And more generally, openness to trade seems to heighten the chance that a country goes through an external adjustment process.

Second, concerning the trade channel, we do systematically find that higher consumer price inflation tends to increase the probability that the country becomes an external adjuster, though the significance of this result is not fully robust.

As to the demand variables, GDP growth and investment growth, the findings warrant some more discussion. Higher investment growth during the boom tends to increase the likelihood of being an internal adjuster which could be interpreted as a sign that an investment driven boom is more benign than a consumption driven one. GDP growth, not unexpectedly, is a poor indicator of the type of exchange rate adjustment. Moreover unit labour cost growth is not proving a good predictor of being an external versus internal adjuster. Further analysis in this regard appears warranted.

As regards fiscal variables, a negative sign for the fiscal balance variable implies that a higher fiscal deficit in the years preceding a bust increases the likelihood that the country becomes an external adjuster during the bust. However, this result is not always statistically significant across different estimations.

While Table 5 reports the overall performance of various models in predicting the exchange rate adjustment, Table 6 reports the specific coefficients and T-values for the two "best models" which illustrate the broader results. 
Table 6: Regression results: two sample (best) models

\begin{tabular}{|c|c|c|}
\hline & Model 1 & Model 2 \\
\hline Investment & $-0.19^{*}$ & \\
\hline Growth & $(1.90)$ & 0.37 \\
& & $(1.58)$ \\
\hline Unit Labour cost & $-0.02^{*}$ & -0.15 \\
& $(-1.84)$ & $(-0.56)$ \\
\hline Credit growth & $0.19^{*}$ & \\
\hline Interest rate & $(1.95)$ & $0.59^{* *}$ \\
& & $(3.10)$ \\
\hline Other portfolio & $0.0003^{* *}$ & \\
investment & $(2.75)$ & $-0.79^{* *}$ \\
\hline Current account & & $(-2.59)$ \\
\hline Fiscal balance & $-0.05^{*}$ & -0.01 \\
& $(-1.81)$ & $(-1.50)$ \\
\hline Total openness & $0.02^{* *}$ & $0.02^{* *}$ \\
& $(6.63)$ & $(2.03)$ \\
\hline
\end{tabular}

significance at $90 / 95 \%$ level.

For these "best models", we checked the predicted role of the exchange rate in adjustment versus the actual incidence of internal versus external adjustment. For 14 out of the 17 countries, the external versus internal adjustment strategy was anticipated correctly for the first model, while it was anticipated correctly for 16 out of the 17 countries for the second model. ${ }^{14}$ The more parsimonious models perform equally well with 15-16 correctly anticipated adjustment strategies. These econometric results, while very preliminary, appear to suggest that domestic and international financial variables best predict the adjustment pattern.

\section{The Central and East European EU Member States}

Finally, we look at the recent experiences and economic situation of nine CEE EU Member States, which can be grouped into two sub-groups, first the three Baltic countries Estonia, Latvia and Lithuania plus Bulgaria (CEE4) and second, the Czech Republic, Hungary, Poland, Romania and Slovakia (CEE5). ${ }^{15}$

For the purposes of this paper there are two key differences between these groups. The CEE4 are a group of (very) small open economies that decided early on in the transformation process to (largely) forego active monetary and exchange rate policy and established currency boards instead. They can thus be considered as internal adjusters. The CEE5 countries are small- to medium-size open economies which, despite significant country-specific differences in their monetary and exchange-rate policy, tend to make more active use of monetary and exchange-rate policy instruments than the CEE4. However, ERM II membership and ultimately euro adoption implies for these countries that they will also have to ultimately move to an internal adjustment strategy (Backé et al. 2004, Schadler et al. 2005) although the timing of this shift will be again country-specific.

As in Section 3.1 we use again Wilcoxon/Mann-Whitney tests for differences in the means of the two country groups (CEE4 and CEE5) and tests of equal Variance (F-tests) for differences in the volatility of the series (see Table 7).

14 For the internal versus external adjustment estimations only 17 countries were included out of 20 since for three countries no bust occurred during the sample period (only a boom).

15 Slovenia has not been included in either of these two groups. With regard to asset price and economic growth development it would fit into the CEE5 group of countries, but it follows an internal adjustment strategy. In fact Slovenia has joined the euro area on 1 January 2007. 
Table 7: Wilcoxon signed ranks test for selected indicators, boom-bust episodes in the CEE4 versus CEE5 countries

\begin{tabular}{|l|c|c|}
\hline & $\begin{array}{c}\text { Median (Wilcoxon/Mann- } \\
\text { Whitney) }\end{array}$ & $\begin{array}{c}\text { Eq. Variance } \\
\text { (F-test) }\end{array}$ \\
\hline REER & \multicolumn{2}{|c|}{ P-value } \\
\hline Real GDP growth & 0.743 & 0.373 \\
\hline Domestic credit growth & $\mathbf{0 . 1 0 0}^{* *}$ & $\mathbf{0 . 0 0 2}$ \\
\hline Inflation & $\mathbf{0 . 0 1 7}$ & $\mathbf{0 . 0 2 0}$ \\
\hline Export growth (volumes) & 0.330 & $\mathbf{0 . 0 0 0 1}$ \\
\hline Export (\% of GDP) & 0.838 & 0.160 \\
\hline $\begin{array}{l}\text { Current account balance, \% of } \\
\text { GDP }\end{array}$ & $\mathbf{0 . 0 3 0}^{* *}$ & $\mathbf{0 . 0 0 9}$ \\
\hline Fiscal balance, \% of GDP & $\mathbf{0 . 0 9 1}^{* *}$ & $\mathbf{0 . 0 8 3}$ \\
\hline Public debt, \% of GDP & $\mathbf{0 . 0 0 4}^{* * *}$ & $\mathbf{0 . 0 1 9}$ \\
\hline
\end{tabular}

Note: $* * * * * / *$ denotes significance at $1 \%, 5 \%$ and $10 \%$ significance levels. Each series has 12 observations covering the period 1994 to 2005. For interest rate, unit labour costs and real estate prices insufficient observations were available to perform the Wilcoxon signed ranks test.

Most variables are found to differ significantly between the CEE4 and the CEE 5 group of countries. Only for the real effective exchange rate, inflation and export growth differences in means and/or volatility are not confirmed. Overall, however, these results suggest that it is indeed analytically meaningful to differentiate between these two sub-groups and to look at the difference in their economic development.

In line with the analytical framework used for industrialised country case studies, we start our stock-taking exercise of the variables underlying the different transmission channels by first looking at real effective exchange rate developments in the CEE4 and the CEE5. Chart B1 shows a trend appreciation of the REER in both country groups. This is not surprising, given that these countries experience a real convergence process towards the euro area (and EU) average. However, the rate of appreciation was stronger over the last few years in the CEE5 countries, whereas the appreciation trend flattened in the CEE4.

Real economic growth in the CEE5 countries was in recent years far below the growth rates of the CEE4. In fact, it was rather similar to growth rates experienced by industrialised countries during boom periods (Chart B2). ${ }^{16}$ By contrast, the rate of economic expansion in the CEE4 countries is very rapid. ${ }^{17}$

Analyses of the domestic financial environment in the CEE countries are unfortunately plagued with severe data problems. ${ }^{18}$ However, the CEE countries have seen very buoyant credit growth in recent years. This applies in particular to the CEE4 (over 50\% in 2005) but also to some CEE5 countries (see Chart B3). ${ }^{19}$ As a result, private sector debt-to-GDP ratios are beginning to increase, especially in the Baltic countries. Although debt is still relatively low compared e.g. to the euro area average (see Chart B4) there are indications that the net financial position of non-financial corporations in the CEE countries is less advantageous than in the euro area (due to a less favourable asset position). Looking at asset price developments, stock markets in the CEE countries

16 On growth prospects in the new central European EU Member States see e.g. Arratibel et al (2007), European Commission (2004) or Wagner and Hlouskova (2002).

17 In fact, only the Asian emerging economies experienced similarly strong rates of economic expansion during their boom period until 1995. This similarity can also be observed for consumption and investment developments.

18 For a detailed overview of credit developments in the CEE countries see Backé and Zumer (2005) or European Central Bank (2006a).

19 Cottarelli et al (2003) do not see the recent evolution of bank credit in Central and Eastern Europe and the Balkans as troublesome. However, the results of their empirical work are based on developments only up to 2003 . 
have mostly experienced very fast growth in the recent past. ${ }^{20}$ Data on house price developments in the CEE countries are unfortunately still rather patchy and heterogeneous. Taken together, however, available country-specific evidence clearly suggests a general picture of very strong growth for real estate prices in the CEECs with real annual house price increases mostly in the double-digit range in recent years. ${ }^{21}$

20 Data on stock market developments are shown in Annex Chart 1.

21 A very useful overview on this issue is provided by Egert and Mihaljek (2007). 

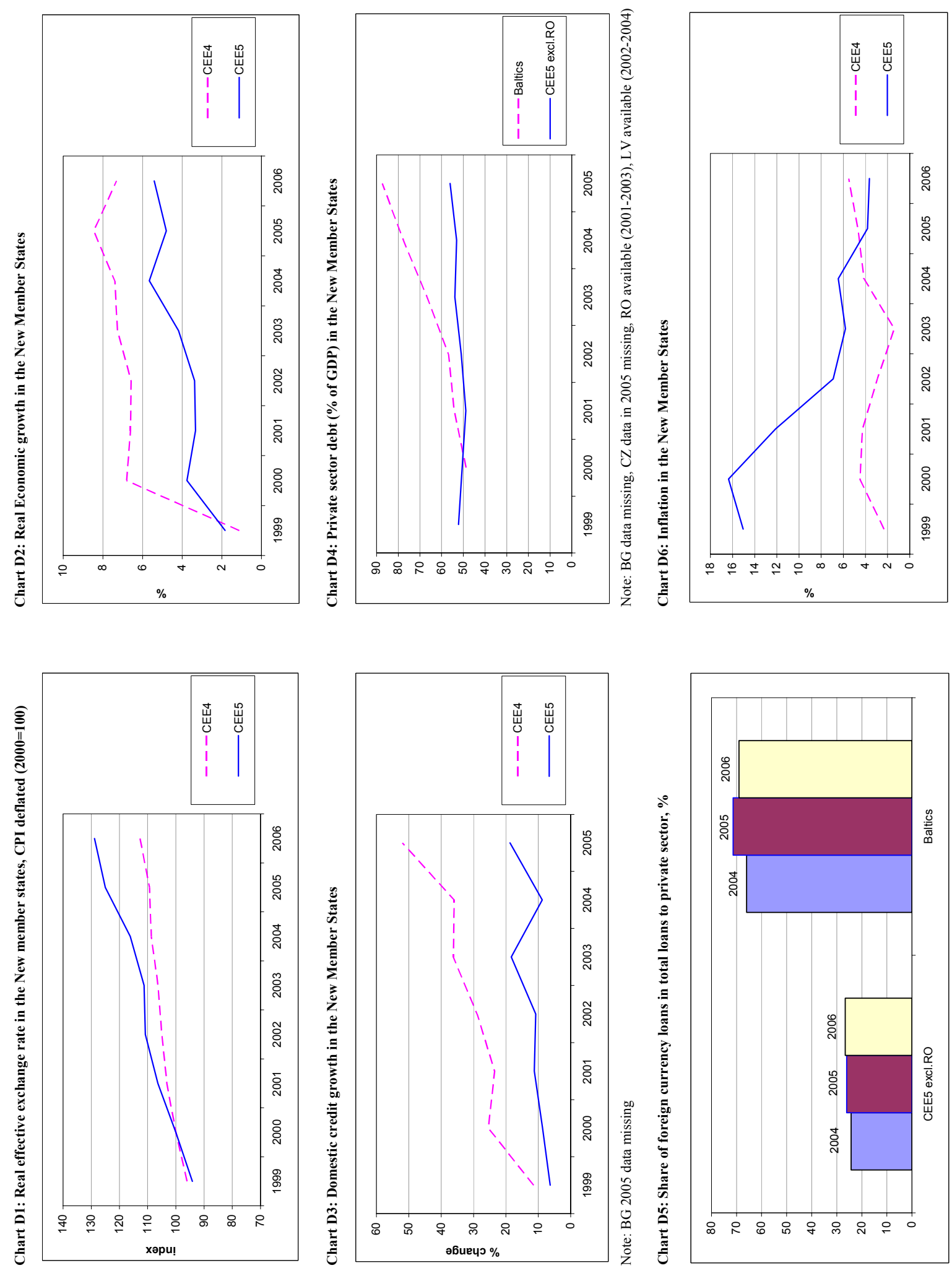

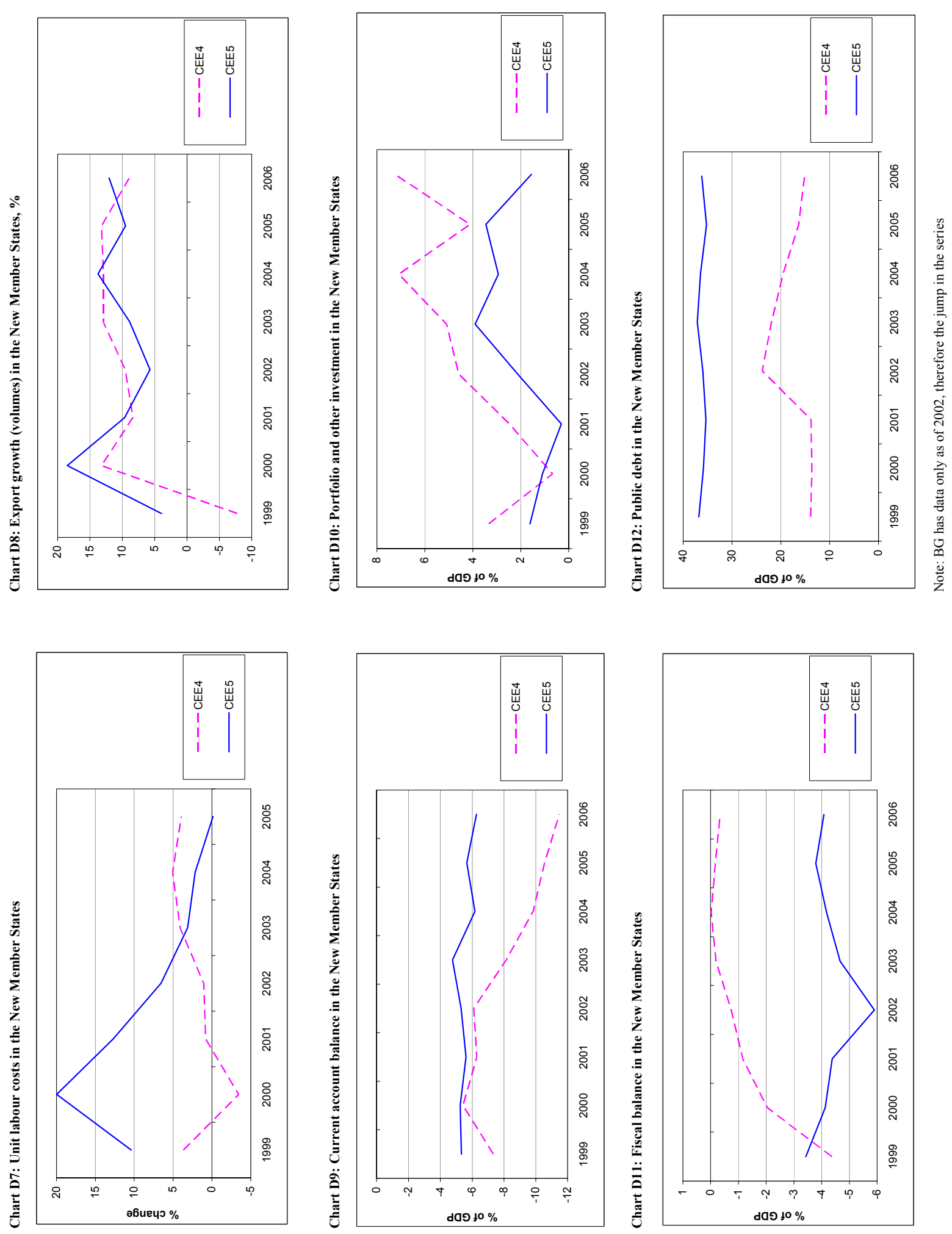
The very dynamic growth of credit in recent years is likely to have been influenced by the strong trend decline in real short-term interest rates observed in the CEE in general and particularly in the CEE4. In fact, real short-term interest rates in the CEE4 have recently fallen to levels below those seen in the groups of external and internal adjusters in the late 1980s. Furthermore, the share of foreign currency loans in per cent of total loans has reached very high levels, in particular in the Baltic countries where long-established currency boards and the associated perception of low currency risks make foreign currency loans with a lower interest rate particularly attractive (see Chart B5). ${ }^{22}$ However, despite the at times considerable exchange rate volatility in the CEE5 countries foreign currency loans also play a sizeable role in this group. This applies not only to euro-denominated loans but also to loans denominated Japanese Yen and Swiss Francs. ${ }^{23}$

Price developments in the CEE4 and the CEE5 since 1999 are characterised by a strong disinflation period in the CEE5 (strongly influenced by initially very high inflation in Romania) and relatively benign inflation between 1999 and 2003 in the CEE4 (see Chart B6). During the last three years, however, inflation in the CEE4 has picked up to levels above 5\%, well above the CEE5 and euro area average.

Turning to the trade and international competitiveness channel, unit labour cost increases in the CEE5 have experienced a trend decline for a number of years largely due to very high gains in productivity (see Chart B7). However, although productivity increases in the CEE4 countries were also quite significant, ULC increase quite strongly in these countries since 2000. This is largely due to increasing wage growth in recent years, which in turn is related to emerging labour market bottlenecks in a very high growth environment.

Export growth was buoyant in both groups of CEE Member States since 2000 although the CEE4 recently experienced a slight decline in export volume growth (see Chart B8). Turning to the current account, however, both country groups show persistent deficits during the entire observation period (see Chart B9). Moreover, current account imbalances in the CEE4 countries worsened considerably since 2002, reaching almost $12 \%$ of GDP in 2006. Given that the CEE countries are catching-up economies, current account deficits are not surprising, also in view of the large investment needs of rapidly transforming economies. However, whereas the gap in investment growth between the CEE4 and the CEE5 averages has recently closed, the current account gap has widened significantly, suggesting that at least part of the CEE4's external imbalance originates from consumption rather than investment. In fact, these are the highest, persistent external imbalances experienced by any of the sample countries in this study.

Looking at the main sources of international finance ${ }^{24}$ used to cover the external imbalances in the CEE countries, some similarities between the sub-groups emerge. FDI inflows are significant in the entire region, although they tended to decrease somewhat in the recent past. This can largely be explained by the trend decline in privatisations in these countries. By contrast, portfolio and other investment increased until 2003 in both country groups. Since then inflows into the CEE5 remained more or less constant respectively decreased in 2006. By contrast, this relatively volatile forms of international capital inflows reached almost 8\% of GDP in the CEE4 in 2004 and again in 2006 (see Chart B10).

Finally, turning to fiscal developments since 1999, public accounts in the CEE4 recovered steadily from the aftermath of the Russian crisis and remained at or close to balance since 2003 (see

\footnotetext{
22 Comparable recent data for Bulgaria and Romania is not available.

${ }^{23}$ The financial sector in CEE countries is very heavily dominated by foreign banks, mostly from the EU. This implies that lending standards are likely to be generally of quite high standards.

24 On international capital flows and the new Member States see e.g. Begg et al. (2003).
} 
Chart B11) ${ }^{25}$ With very strong growth in recent years, the CEE4 record nearly balanced fiscal accounts on average. By contrast, fiscal balances in the CEE5 countries gradually deteriorated until 2002 and only the last few years saw some moderate improvement. As a result, public debt in the CEE5 remained close to $40 \%$, still well below the EU average but well above the public debt ratio afforded by most emerging markets (Afonso, Nickel and Rother, 2005) (see Chart B12).

Summing up, the CEE countries are currently experiencing a period of strong credit and asset price growth in conjunction with rapid economic expansion. On the basis of the stylised facts discussion above, this pattern appears more pronounced and advanced in the CEE4 countries while the CEE5 countries seem to be at an earlier stage of the process.

\section{Conclusions}

This study has derived stylised facts and some preliminary statistical and econometric analysis for a number of boom - bust episodes in asset prices in industrialized countries, notably as regards the role of the exchange rate in the adjustment process. It distinguishes external adjustment with real effective exchange rate devaluation versus internal adjustment without such devaluation).

The findings support the claim that real and financial variables interact in boom-bust episodes where asset price cycles and their impact on private balance sheets constitute an important driving force. Most importantly, countries' different exchange rate adjustment experiences are correlated with the extent of macroeconomic imbalances and the degree of balance sheet vulnerability. Together with relatively loose fiscal policies, this stoked asset price and consumer price inflation and domestic demand. At the same time it reinforced competitiveness losses in the boom which when fortunes reversed - exacerbated the bust and the resulting adjustment needs. In those cases where the exchange rate was devalued, this shift in policy first reinforced balance sheet problems in the private sector but then precipitated a rapid recovery. From this we conclude:

- External adjusters tend to experience more pronounced booms with more overheating of demand, increases in prices and credit, loss of competitiveness and deterioration of (private sector, external and public) balance sheets than reported for internal adjusters.

- In busts, external adjusters tend to experience deep downturns and rapid recoveries as imbalances are initially more severe but, subsequently, also unwind more quickly. Internal adjusters tend to face less deep but more protracted downturns as imbalances unwind more slowly and adjustment via the trade and credit channels takes more time.

- Statistical and preliminary econometric analysis broadly confirms stylised facts on boom bust episodes, with domestic and international financial variables appearing to have the most significant predictive power for the role of the exchange rate in adjustment.

The study seems to confirm many "orthodox" messages:

- The more significant demand and financial excesses, competitiveness loss, and fiscal and external imbalances in the course of the boom the more likely it seems that a country would be found in the group of external adjusters in the bust.

- Internal adjustment appears to be more prevalent when external and fiscal imbalances are small, and when credit growth, inflation and competitiveness loss is contained during the boom.

25 For a useful overview of fiscal developments in most CEE countries see the ECB's Convergence Reports in 2006 (ECB 2006b and ECB 2006c). 
Stylised facts for the CEE EU Member States suggest that they are currently experiencing a period of strong credit and asset price growth in conjunction with rapid economic expansion. This pattern appears more pronounced and advanced in the CEE4 countries while the CEE5 countries seem to be at an earlier stage of the process.

Clear and definite conclusions as to the situation and prospects can not be drawn for the CEE EU Member States, not least due to the serious data problems for these countries as well as the difficulties in distinguishing booms from catching-up effects. In addition, the institutional framework provided by EU membership and the prospect of euro adoption - once the CEE countries fulfill the Maastricht convergence criteria - are specific to this group of countries. Nevertheless the experiences of other countries may raise awareness of related policy challenges in the CEE countries. 


\section{References}

Afonso, António, Christiane Nickel and Philipp Rother (2005) Fiscal Consolidations in the Central and Eastern European Countries. ECB Working Paper Series No.473/2005

Allen, Mark, Christoph Rosenberg, Christian Keller, Brad Setser, and Nouriel Roubini (2002) A Balance Sheet Approach to Financial Crisis, IMF Working Paper, WP/02/210.

Arratibel, Olga, Frigyes Heinz, Reiner Martin, Marcin Przybyla, Lukasz Rawdanowicz, Roberta Serafini and Tina Zumer (2007) Real Convergence in the new EU Member States - A production function approach, ECB Occasional Paper 61.

Backé, Peter and Tina Zumer (2005) Developments in Credit to the Private Sector in Central and Eastern European EU Member States: emerging from Financial Repression -A Comparative Overview, in Focus on European Economic Integration 2/05, OeNB, 2005, p.83-109.

Backé, Peter, Christian Thimann, Olga Arratibel, Oscar Calvo-Gonzalez, Arnaud Mehl and Carolin Nerlich (2004) The Acceding Countries' Strategies Towards ERM II and the Adoption of the Euro: An Analytical Review ECB Occasional Paper Series No. 10.

Begg, D., B. Eighengreen, L. Halpern, J. von Hagen and C. Wyplosz (2003) Sustainable Regimes of Capital Movements in Accession Countries CEPR policy Paper No. 10

Bernanke, Ben, Mark Gertler and Simon Gilchrist (1999) The Financial Accelerator in a Quantitative Business Cycle Framework. In J.B. Taylor and M. Woodford (eds.) Handbook of Macroeconomics, Vol. I

Bordo, Michael D. and Olivier Jeanne (2002) Monetary Policy and Asset Prices: Does "Benign Neglect" Make Sense? IMF Working Paper WP/02/225

Borio, Claudio and Philip Lowe (2002) Asset Prices, Financial and Monetary Stability: Exploring the Nexus. BIS Working Paper No. 114.

Borio, Claudio, N. Kennedy and S.D. Prowse (1994) Exploring Aggregate Asset Price Fluctuations Across Countries, Measurements, Determinants and Monetary Policy Implications. BIS Economic Papers No. 40.

Borio, Claudio (2005) The search for the elusive twin goals of monetary and financial stability, paper presented at the 2nd DG ECFIN Research Conference, European Commission, October 2005.

Calvo, Guillermo A., Alejandro Izquierdo and Luis-Fernando Mejia (2004) On the Empirics of Sudden Stops: the Relevance of Balance-Sheet Effects. NBER Working Paper 10520

Calvo, Guillermo A., Alejandro Izquierdo and Ernesto Talvi (2003) Sudden Stops, the Real Exchange Rate, and Fiscal Sustainability: Argentina's Lessons. NBER Working Paper 9828

Campos, Nauro F. and Yuko Kinoshita (2003) Why does FDI Go Where it Goes? New Evidence from the Transition Economies. IMF Working Paper WP/03/228

Cottarelli, C, Giovanni Dell'ariccia and Ivanna Vladkova-Hollar, Early Birds, Late Risers and Sleeping Beauties: Bank Credit Growth to the Private Sector in Central and Eastern Europe and the Balkans, IMF Working Paper WP/03/213

Detken, Carsten and Frank Smets (2004) Asset price booms and monetary policy, in: Horst Siebert (ed.), "Macroeconomic Policies in the World Economy", Springer, Berlin.

Égert, Balász and Mihaljek, Dubravko (2007) Determinants of House prices in central and eastern Europe, forthcoming

European Central Bank (2006a), Financial development in central, eastern and south-eastern Europe, Monthly Bulletin November, 93-104 
European Central Bank (2006b), Convergence Report May 2006, May.

European Central Bank (2006b), Convergence Report December 2006, December.

Eichengreen, Barry and Omar Choudhry (2005) Managing Capital Inflows: Eastern Europe in an Asian Mirror.

Eschenbach, Felix and Ludger Schuknecht (2004) Budgetary Risks From Real Estate and Stock Markets, Economic Policy, 315-348.

European Commission (2004), The EU Economy: 2004 Review, European Commission, Brussels.

Fagan, Gabriel and Vitor Gaspar (2005) Is Boom and Bust Part of Adjustment to Participation in the Euro Area? Frankfurt/Lisbon: Mimeo.

Finger, K. Michael and Ludger Schuknecht (1999) Trade, Finance and Financial Crises. WTO Special Studies 3

Harding, Don and Adrian Pagan (2002) Dissecting the Cycle: A Methodological Investigation. Journal of Monetary Economics, Vol. 49 (pp. 265-81)

Honohan, Patrick and Daniela Klingebiel (2003) The Fiscal Cost Implications of an Accommodating Approach to Banking Crises. Journal of Banking \& Finance 27

International Monetary Fund (2000) World Economic Outlook, Ch. III: Asset Prices and the Business Cycle, 77-112.

Jaeger, Albert and Ludger Schuknecht (2004) Boom-Bust Phases in Asset Prices and Fiscal Policy Behavior. IMF Working Paper WP/04/54

Jonung, Lars, Ludger Schuknecht and Mika Tujula (2005) The Boom-Bust Cycle in Finland and Sweden 1985-2000 in an International Perspective, forthcoming in Lars Jonung.

Jonung, Lars and Lars Stymne (1997) The Great Regime Shift: Asset Markets and Economic Activity in Sweden, 1985 - 93. In Capie, Forrest H. (ed.) 1997 Asset Prices and the Real Economy (pp.19-55)

Komulainen, Tuomas (2004) Essays on Financial Crises in Emerging Markets, Helsinki: Bank of Finland Studies.

Schadler, Susan, Paulo Drummond, Louis Kuijs, Zuzana Murgasova and Rachel van Elkan (2005) Adopting the Euro in Central Europe: Challenges of the Net Step in European Integration IMF Occasional Paper No. 234

Sinn, Hans Werner (2004) Ist Deutschland noch zu retten? Berlin: ECON.

Wagner, Martin and Jaroslava Hlouskova (2002) The CEEC10s Real Convergence Prospects Centre for Economic Policy Research Discussion Paper No 3318.

Watson, Max (2005) Financial Stability in Macroeconomic Surveillance: Converging Economies, Brussels: Mimeo.

$\mathrm{Xu}$, Jun and Scott Long (2005). Confidence Intervals for Predicted Outcomes in Regression Models for Categorical Outcomes. Mimeo, Indiana University. 


\section{Annex Table: Data and Sources}

Real effective exchange rate (REER): IMF/WEO da ta base, Global Insight/World Market Monitor database and ECB.

Real economy/demand channel

Real economic growth: OECD/OEO database and IMF/WEO database.

Real private consumption: OECD/OEO database and IMF/WEO database.

Real private investment: OECD/OEO and IMF/WEO database, European

Commission/AMECO database and Eurostat.

Total employment: OECD/OEO database and IMF/WEO database and European

Commission/AMECO database.

Domestic financial/credit channel

Asset price/real estate price indices: BIS, Hong Kong Monetary Authority

Credit: IMF/IFS data base.

Loans: ECB.

Private debt: ECB

Real short-term interest: OECD/OEO.

Inflation: OECD/OEO database and IMF/WEO database.

Trade/competitiveness channel

Real unit la bour costs: OECD/OEO database and IMF/WEO database, and Eurostat.

Export volumes: IMF/WEO database.

Import volumes: IMF/WEO database.

Exports: IMF/WEO database.

Imports: IMF/WEO database.

International financial channel

Current account balance: OECD/OEO database and IMF/WEO database.

Foreign Direct Investment: IMF/WEO database.

Portfolio: IMF/WEO database.

Other investment: IMF/WEO database.

Fiscal channel

Fiscal balance (adjusted for one-off UMTS rec eipts): OECD/OEO database and IMF/WEO database.

Public debt: OECD/OEO database and IMF/WEO database and European

Commission/AMECO da tabase. 


\section{European Central Bank Working Paper Series}

For a complete list of Working Papers published by the ECB, please visit the ECB's website (http://www.ecb.int)

758 "Red tape and delayed entry" by A. Ciccone and E. Papaioannou, June 2007.

759 "Linear-quadratic approximation, external habit and targeting rules" by P. Levine, J. Pearlman and R. Pierse, June 2007.

760 "Modelling intra- and extra-area trade substitution and exchange rate pass-through in the euro area" by $A$. Dieppe and T. Warmedinger, June 2007.

761 "External imbalances and the US current account: how supply-side changes affect an exchange rate adjustment" P. Engler, M. Fidora and C. Thimann, June 2007.

762 "Patterns of current account adjustment: insights from past experience" by B. Algieri and T. Bracke, June 2007.

763 "Short- and long-run tax elasticities: the case of the Netherlands" by G. Wolswijk, June 2007.

764 "Robust monetary policy with imperfect knowledge" by A. Orphanides and J. C. Williams, June 2007.

765 "Sequential optimization, front-loaded information, and U.S. consumption" by A. Willman, June 2007.

766 "How and when do markets tip? Lessons from the Battle of the Bund" by E. Cantillon and P.-L. Yin, June 2007.

767 “Explaining monetary policy in press conferences” by M. Ehrmann and M. Fratzscher, June 2007.

768 "A new approach to measuring competition in the loan markets of the euro area" by M. van Leuvensteijn, J. A. Bikker, A. van Rixtel and C. Kok Sørensen, June 2007.

769 “The 'Great Moderation' in the United Kingdom” by L. Benati, June 2007.

770 "Welfare implications of Calvo vs. Rotemberg pricing assumptions" by G. Lombardo and D. Vestin, June 2007.

771 "Policy rate decisions and unbiased parameter estimation in typical monetary policy rules" by J. Podpiera, June 2007.

772 "Can adjustment costs explain the variability and counter-cyclicality of the labour share at the firm and aggregate level?" by P. Vermeulen, June 2007.

773 "Exchange rate volatility and growth in small open economies at the EMU periphery" by G. Schnabl, July 2007.

774 "Shocks, structures or monetary policies? The euro area and US after 200I" by L. Christiano, R. Motto and M. Rostagno, July 2007.

775 "The dynamic behaviour of budget components and output" by A. Afonso and P. Claeys, July 2007.

776 "Insights gained from conversations with labor market decision makers" by T. F. Bewley, July 2007.

777 "Downward nominal wage rigidity in the OECD" by S. Holden and F. Wulfsberg, July 2007. 
778 “Employment protection legislation and wages” by M. Leonardi and G. Pica, July 2007.

779 "On-the-job search and the cyclical dynamics of the labor market" by M. U. Krause and T. A. Lubik, July 2007.

780 "Dynamics and monetary policy in a fair wage model of the business cycle" by D. de la Croix, G. de Walque and R. Wouters, July 2007.

781 “Wage inequality in Spain: recent developments” by M. Izquierdo and A. Lacuesta, July 2007.

782 "Panel data estimates of the production function and product and labor market imperfections" by S. Dobbelaere and J. Mairesse, July 2007.

783 "The cyclicality of effective wages within employer-employee matches - evidence from German panel data" by S. Anger, July 2007.

784 "Understanding the dynamics of labor shares and inflation" by M. Lawless and K. Whelan, July 2007.

785 “Aggregating Phillips curves” by J. Imbs, E. Jondeau and F. Pelgrin, July 2007.

786 "The economic impact of merger control: what is special about banking?" by E. Carletti, P. Hartmann and S. Ongena, July 2007.

787 "Finance and growth: a macroeconomic assessment of the evidence from a European angle" by E. Papaioannou, July 2007.

788 "Evaluating the real effect of bank branching deregulation: comparing contiguous counties across U.S. state borders" by R. R. Huang, July 2007.

789 "Modeling the impact of external factors on the euro area's HICP and real economy: a focus on pass-through and the trade balance” by L. Landolfo, July 2007.

790 "Asset prices, exchange rates and the current account" by M. Fratzscher, L. Juvenal and L. Sarno, August 2007.

79I "Inquiries on dynamics of transition economy convergence in a two-country model" by J. Brůha and J. Podpiera, August 2007.

792 "Euro area market reactions to the monetary developments press release" by J. Coffinet and S. Gouteron, August 2007.

793 "Structural econometric approach to bidding in the main refinancing operations of the Eurosystem" by N. Cassola, C. Ewerhart and C. Morana, August 2007.

794 “(Un)naturally low? Sequential Monte Carlo tracking of the US natural interest rate” by M. J. Lombardi and S. Sgherri, August 2007.

795 "Assessing the Impact of a change in the composition of public spending: a DSGE approach" by R. Straub and I. Tchakarov, August 2007.

796 "The impact of exchange rate shocks on sectoral activity and prices in the euro area" by E. Hahn, August 2007.

797 "Joint estimation of the natural rate of interest, the natural rate of unemployment, expected inflation, and potential output" by L. Benati and G. Vitale, August 2007. 
798 "The transmission of US cyclical developments to the rest of the world" by S. Dées and I. Vansteenkiste, August 2007.

799 "Monetary policy shocks in a two-sector open economy: an empirical study" by R. Llaudes, August 2007.

800 "Is the corporate bond market forward looking?" by J. Hilscher, August 2007.

80I "Uncovered interest parity at distant horizons: evidence on emerging economies \& nonlinearities" by A. Mehl and L. Cappiello, August 2007.

802 "Investigating time-variation in the marginal predictive power of the yield spread" by L. Benati and C. Goodhart, August 2007.

803 "Optimal monetary policy in an estimated DSGE for the euro area" by S. Adjemian, M. Darracq Pariès and S. Moyen, August 2007.

804 "Growth accounting for the euro area: a structural approach" by T. Proietti and A. Musso, August 2007.

805 "The pricing of risk in European credit and corporate bond markets" by A. Berndt and I. Obreja, August 2007.

806 "State-dependency and firm-level optimization: a contribution to Calvo price staggering" by P. McAdam and A. Willman, August 2007.

807 “Cross-border lending contagion in multinational banks" by A. Derviz and J. Podpiera, September 2007.

808 "Model misspecification, the equilibrium natural interest rate and the equity premium" by $\mathrm{O}$. Tristani, September 2007.

809 “Is the new Keynesian Phillips curve flat?" by K. Kuester, G. J. Müller und S. Stoelting, September 2007.

810 "Inflation persistence: euro area and new EU Member States” by M. Franta, B. Saxa and K. Šmídková, September 2007.

8II "Instability and nonlinearity in the euro area Phillips curve” by A. Musso, L. Stracca and D. van Dijk, September 2007.

812 “The uncovered return parity condition” by L. Cappiello and R. A. De Santis, September 2007.

813 "The role of the exchange rate for adjustment in boom and bust episodes" by R. Martin, L. Schuknecht and I. Vansteenkiste, September 2007. 
